\title{
The Wall Street Consensus
}

\author{
Daniela Gabor (UWE Bristol)
}

\begin{abstract}
The Wall Street Consensus is an elaborate effort to reorganize development interventions around partnerships with global finance. The Billions to Trillions agenda, the World Bank's Maximising Finance for Development or the G20's Infrastructure as an Asset Class all call on international development institutions and governments of poor countries to 'escort capital' - institutional investors and the managers of their trillions in assets - into investable development assets. For this, ten policy commandments aim to forge the de-risking state and accelerate the structural transformation of local financial systems towards market-based finance. The state riskproofs development assets for institutional investors by taking on its balance sheet: (i) demand risks attached to commodified (social) infrastructure assets, (ii) political risk attached to policies that would threaten profits, such as nationalization, higher minimum wages and climate regulation, (iii) climate risks that may become part of regulatory frameworks; (iv) bond and currency markets risks that complicate investors' exit. The new 'development as derisking' paradigm narrows the scope for a green developmental state that could design a just transition to low-carbon economies.
\end{abstract}




\section{INTRODUCTION}

'....we have to start by asking routinely whether private capital, rather than government funding or donor aid, can finance a project. If the conditions are not right for private investment, we need to work with our partners to de-risk projects, sectors, and entire countries'.

Jim Yong Kim, World Bank Group President (2017)

The international development literature made two notable predictions over the past twenty years. It announced the (overdue) death of the Washington Consensus paradigm (Gore, 2000; Rodrik 2006). Anchored in the work of John Williamson (1990, 1993), the Washington Consensus outlined ten policy areas that would set countries on firm market foundations, under a 'holy Trinity' of macroeconomic stabilization through lower inflation and fiscal discipline; liberalization of trade and capital flows, of domestic product and factor markets; and privatization of state companies. After the East Asian crisis, against the poor performance of countries closely wedded to the Washington Consensus prescriptions (Rodrik, 2006; Fischer, 2019) and the revolt of notable insiders such as Joseph Stiglitz, Gore (2000) announced an Asian developmental model, updated to the 'age of global money' (Yanagihara and Sambommatsu, 1996). The collapse of Lehman Brothers brought the second notable prediction: the end of the age of global money and its 'foreign finance fetish' (Birsdall and Fukuyama, 2011).

Both predictions turned out wrong. Financial globalization is alive and well, and sets the particular context in which 'international development' is pursued in the $21^{\text {st }}$ century. As Lord Stern, of the influential G20 Eminent Persons Group, put it: 'the challenge of achieving the Sustainable Development Goals (SDG) is in large measure that challenge, of fostering the right kind of sustainable infrastructure', for which, 'you have to have good finance, the right kind of finance, at the right scale, at the right time' ${ }^{1}$. The new development mantra, spelled out in the Billions to Trillions agenda, the World

\footnotetext{
${ }^{1}$ http://live.worldbank.org/implenting-SDGs-changingworld?CID=ECR_TT_worldbank_EN_EXT_AM2018-sdgs
} 
Bank's Maximising Finance for Development, or the G20 Infrastructure as an Asset Class, aims to create investable development projects that can attract global investors and orient their trillions into financing the SDG ambitions. For instance, at the 2017 launch of the Maximising Finance for Development, the World Bank promised global investors \$12 trillion in market opportunities that include "transportation, infrastructure, health, welfare, education', minted into bankable/investible projects via public-private partnerships (PPPs). These are long-term contractual arrangements through which the private sector commits to finance, construct and manage public services as long as the state, with multilateral development bank support via blended finance, shares the risks to guarantee payment flows to PPP operators and investors.

This shift in the development agenda can be conceptualized as the Wall Street Consensus, an emerging 'Development as Derisking' paradigm that reframes the (Post) Washington Consensus (Öniş and Senses, 2005) in the language of the Sustainable Development Goals, and identifies global finance as the actor critical to achieving the SDG. To explore its contours, the article draws on scholarly accounts of the financialisation of development, understood as strategies to 'escort' financial capital into derisked asset classes (Carroll and Jarvis, 2014; Baker, 2015; Mawdsley, 2018; Bigger and Webber, 2020). While these micro-level accounts emphasize the role of MDBs or donor agencies, the state's macro-financial policies and the growing importance of institutional investors' demand for development asset classes is largely ignored (see Musthaq, 2020 for an exception). To fill in the gap, the article draws on a critical macrofinance approach concerned with the co-evolution of global finance and the macro-institutions of the state (Gabor, 2020). In the age of institutional investors and asset managers that move capital across border via portfolio flows, (subordinated) financialisation is no longer confined to the balance sheet of banks and non-financial corporations, but becomes a state-mediated project of constructing new development asset classes (Dafermos et al, 2020a, b; Musthaq, 2020).

Through this lens, the WSC is an attempt to re-orient the institutional mechanisms of the state towards protecting the political order of financial capitalism against climate justice movements and Green New Deal initiatives (Wainwright and Mann, 2018). Development as derisking starts with the question 'how to make projects bankable', or how to construct investible development asset classes. In answering that question, the 
InterAmerican Development Bank (2017) suggests, 'the first thing Multilateral Development Banks should be asking themselves is "will people pay to use it?" Investors are far more confident in returns when projects have a built-in set of users who are willing to pay'. But this is not simply an agenda to privatize infrastructure. Making development 'investible' requires a two-pronged strategy: (a) enlist the state into derisking development asset classes, to ensure steady cash flows for investors and (b) re-engineer local financial systems in the image of US market-based finance to allow global investors' easy entry into, and exit from, new asset classes. Thus, Wall Street Consensus marks a new moment in capitalist accumulation, from what David Harvey (2003) termed 'accumulation by dispossession' to accumulation by de-risking.

The state building project in the Wall Street Consensus is more ambitious than the PostWashington Consensus tolerance of the state as corrector of market failures, through regulation and poverty alleviation (Öniş and Senses, 2005). The derisking state creates a safety net for the holders of development assets, protecting their profits from demand risks attached to infrastructure assets; from political risks attached to policies that would threaten cash flows, including nationalization, higher minimum wages and, critically, climate regulation; and from bond liquidity and currency risks. These risks are transferred to the balance sheet of the state.

The practice of de-risking goes back to the developmental state, but its politics changed. The developmental state 'de-risked' domestic manufacturing in priority, mainly export, sectors through industrial policies (Wade, 2018). It was successful where it had the capacity to discipline local capital (Öniş, 1991), to govern market failures through evolving institutional structures (Haggard 1990, 2018) and to generate elite support for the developmental state as a political project (Mkandawire, 2001). In its modern version, the entrepreneurial state adopts a "mission-oriented" market-shaping approach that shares the risks and returns with highly-innovative private industries (Mazzucato 2016). In contrast, the WSC state de-risks development asset classes for global institutional investors without the embedded autonomy of the developmental state (Evans, 1991). It lacks an autonomous strategic vision, unless 'more infrastructure' can be described as such, and has fewer tools to discipline global finance.

The emerging WSC is a template, but not a straightjacket. It requires local political 
coalitions to consolidate around the de-risking state, to deliver on its demands and to diffuse political contestation. Indeed, before the COVID19 pandemic, the pace of new PPP infrastructure investment lagged behind the ambitions of the WSC promoters, highlighting the complexity of the institutional transformation required to scale-up the production of derisked development asset classes (Dafermos et al, 2020b). Yet the macrofinancial processes set in motion by the COVID19 pandemic, in particular the rapid rise in public debt and the growing public commitments to fight the climate crisis, have renewed the political momentum behind this ambition. The Global Investors for Sustainable Development Alliance (2020), working under the auspices of the United Nations, called for 'reinvigorating PPPs to a degree not experienced since World War II - and a degree that has perhaps never been seen in peacetime' in the aftermath of the COVID19 pandemic. Similarly, the UN Climate Change conference (COP26) stream on private finance called for 'bespoke solutions' for developing countries that include 'public-private partnerships, pipelines of bankable projects, and new market structures, to facilitate commercially viable opportunities for sustainable investment' (Carney, 2020).

The WSC downplays the risks of the macro-financial order it seeks to impose. It engineers financial globalization that increases vulnerability to volatile capital flows (Rey, 2015). In prioritizing market access, the Grand Bargain with private finance protects bondholders from participating in debt renegotiations or debt service suspension that poor and emerging countries require when under they come under the pressure of large shocks such as the COVID19 pandemic or extreme climate events. Perhaps more importantly, it threatens developmental policy space by narrowing the scope for a green developmental state that could design a just transition to low-carbon economies, where the burden of structural change does not disproportionately fall on the poor.

To trace these reconfigurations, the paper explores the policy documents produced by WSC institutions (World Bank, other MDBs, the IMF) and private finance. It focuses on the World Bank's new instrument for the Maximising Finance for Development strategy, entitled Infrastructure Sector Assessment Programs (InfraSAP), applied to 
Egypt, Nepal, Sri Lanka and Vietnam ${ }^{2}$ by mid 2020. The paper finally provides a short reflection on the insights that the COVID19 pandemic offers into the grand bargain with private finance.

\section{DEVELOPMENT AS DERISKING: A FRAMEWORK}

If the Washington Consensus was a coordinated campaign for the global diffusion of market-led policies (Babb and Kentikelenis, 2020), then the WSC coordinates a new modality of state governance focused on derisking. It is grounded in a rhetoric of partnerships, between state and private finance, between Global South governments and the private sector, between donor governments, private sector and voluntary sectors with 'a shared vision, and shared goals' (UN, 2015). Dispensing with the legitimizing force of neoclassical economics in the Washington Consensus, development is narrated as a matter of closing funding gaps through partnerships with (global) institutional investors, while development interventions are defined as policies that create risk buffers to render development projects 'investible'.

The practice of 'escorting' private capital started to shape development interventions in the 1990s, under the ideological cover of the Washington Consensus. Spearheading it, the German development bank KfW obtained political support for using concessional resources as a risk buffer, to subsidise the high-risk tranche of development-oriented financial instruments, including 'equity stakes in microfinance, first-loss risk absorption in structured funds, and guarantees for the issuances of green bonds' (Volberding 2018, p.17, also Banse 2019).

The rhetoric of risk sharing morphed into derisking when Deutsche Bank and the UNDP (2011) proposed an innovative de-risking partnership for renewable energy markets in the Global South. The state has two modalities for derisking: regulatory and financial. Regulatory derisking targets regulatory barriers that obstruct private producers (dismantling vertically integrated, state-owned energy monopoly utilities; redirecting public subsidies from fossil fuel to renewable energy producers via feed-in

\footnotetext{
${ }^{2}$ The publication of InfraSAP for Indonesia, one of the keenest supporters of the MFD approach, initially expected in January 2019, was delayed after public outcry over a leaked draft.
} 
tariffs, guaranteed grid access). In turn, financial derisking captures a range of public subsidies and guarantees including direct grants, tax relief, debt-base instruments (preferential credit, loan guarantees, first loss equity tranches in private equity funds, green bonds).

The political technologies of derisking (Sweerts et al 2019; Müller, 2020) became more clearly defined when the UNDP (2013) points to global institutional investors as critical sources for closing the renewable funding gap. To attract such investors, the UNDP argued, countries with low sovereign ratings such as Mongolia or Kenya need more than regulatory derisking. The poorer the country, the more financial derisking (ie. transfers of risks that investors face to the state) is required.

The inclusion of institutional investors - from pension funds to insurance companies and sovereign wealth funds - and asset managers as critical stakeholders upgrades the derisking renewables strategy into a full-blown, ambitious 'development as derisking' paradigm. With notable exceptions (Mushtaq, 2020), institutional investors and asset managers have passed mostly unnoticed in scholarship on the financialisation of development. But their systemic importance in WSC circles is not accidental. It reflects the political economy of macrofinancial reform in high-income countries after the global financial crisis (see Dafermos et al 2020b, also Braun 2020a). Worried primarily by the 'global banking glut' (Shin, 2011), that is, excessive cross-border global bank lending, high-income countries tightened global banking rules while simultaneously promoting market-based finance, a 'resilient' form of shadow banking dominated by institutional investors and their asset managers. The growing footprint of these 'new powerbrokers of modern capital markets' (Fisch et al, 2018, also Fichtner et al. 2017) reflects the weakening capacity of the state to tax multinational corporations and highnet worth individuals (that pour their cash into institutional investment vehicles) and to provide traditional welfare to its citizens via public health, pensions, education (prompting them to turn to asset-based welfare via pension funds and insurance companies), often under the pressure of fiscal austerity discourses. These political forces together have created a portfolio glut. Mirroring the 'banking glut' of the pre2008 period of financial globalisation, generated by a handful of global banks, the portfolio glut is also characterised unprecedented concentration of capital in the hands of a few global asset managers such as Blackrock (Braun, 2020b). 
Institutional investors and asset managers move capital across borders via portfolio flows into debt (bonds) and equity markets. The portfolio glut is studied in the capital flow management literature through Rey's (2015) global financial cycle, the idea that financial globalisation creates a trade-off between monetary policy autonomy and free capital flows, rendering middle-income and poor countries vulnerable to US dollar financing conditions. Whereas that literature asks how to address systemic vulnerabilities (Bortz and Kaltenbrunner, 2018), in the Wall Street Consensus, the question becomes how to market development to global portfolio investors with specific investment mandates. The answer often starts with derisking PPP infrastructure assets, as institutional investors argue that more than half of infrastructure projects in emerging countries are not investible because their risk architecture does not create their preferred cash flow characteristics ${ }^{3}$. The new development question does not just allow institutional investors to increasingly shape both global initiatives such as the G20 (2018) Infrastructure as an Asset Class ${ }^{4}$ and national infrastructure spaces ${ }^{5}$, but creates demands for a new 'derisking' mode of governance for states in the Global South.

To broadly map the derisking state, compare it with the alternative of a green developmental state as conceptualised in Green New Deal initiatives, a variant of the developmental state upgraded for the age of the climate crisis (UNCTAD 2019, for a post-colonial critique see Aj1 2018, also Perry 2020). In the state-based model, largescale public investment, often via development banks, is directed towards public green infrastructure, which citizens access freely, although they may be taxed for it. It can involve institutional investors where the state chooses to issue government bonds or green/SDG bonds in order to finance its investments, particularly if these involve imports to be paid in foreign currency. It needs to contend with questions of democratic participation and truly just transition that does not dismiss grassroots experiences

3 For instance, a common rule of thumb is that pension funds need a minimum $4 \%$ return plus inflation. See https://realassets.ipe.com/reports/infrastructure-as-asset-class-a-briefhistory/realassets.ipe.com/reports/infrastructure-as-asset-class-a-briefhistory/10026752.fullarticle

4 See Blackrock (2015).

5 Between 2012 and 2018, Blackrock was a prime beneficiary of president Pena Nieto's PPPdriven infrastructural projects, acquiring infrastructure assets through revolving door relationships. In his campaign, the left-wing Lopez Obrador denounced Blackrock as whitecollar financial mafia, but gave up the campaign promise to review Blackrock PPP contracts once he won the presidency in 2019 (Blackrock Transparency Project, 2019). 
(White, 2020), indigenous communities (Indigenous Environmental Network, 2018) and post-carbon solidarity economies (Akuno and Nangwaya, 2017).

Figure 1 The Green Developmental State vs the Derisking State

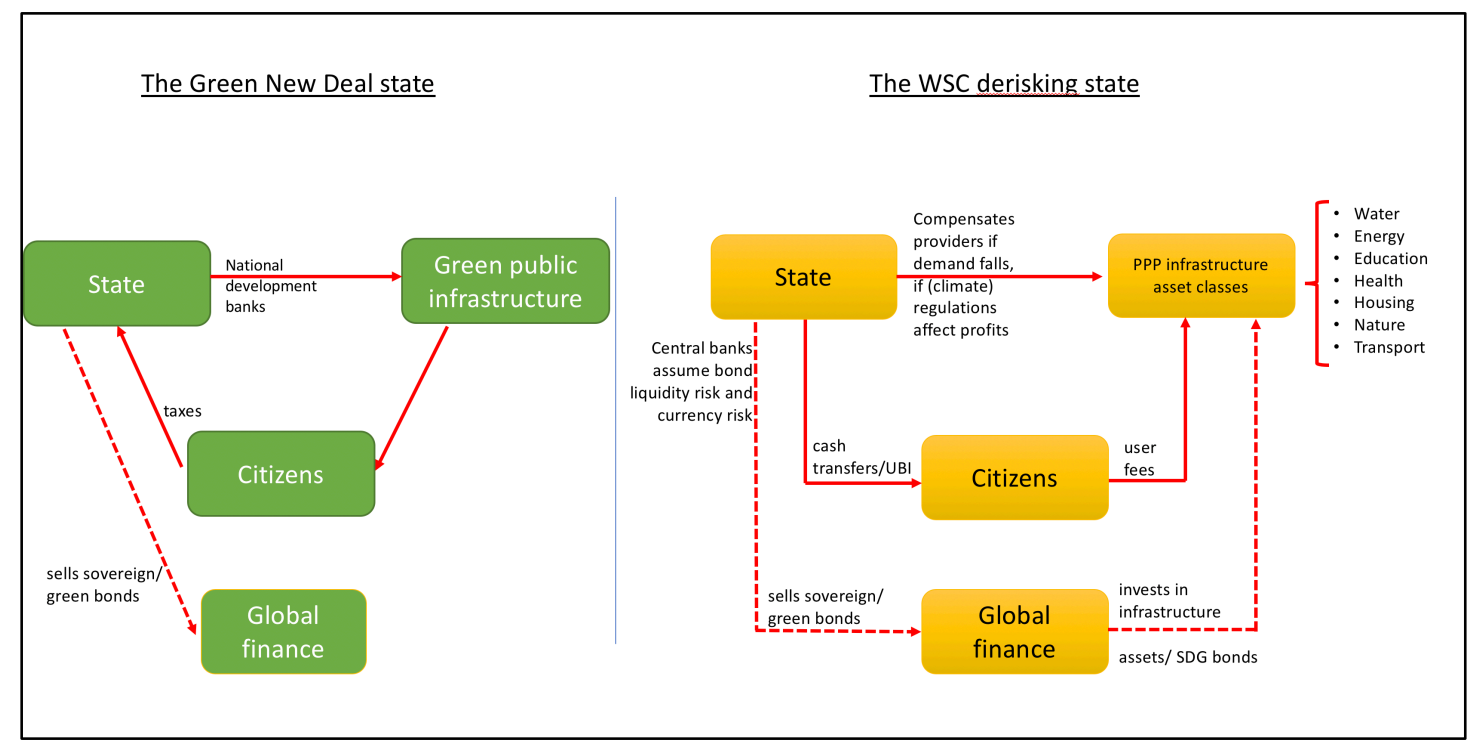

In the derisking mode of governance, the state designs a menu of sector-specific policy and financial derisking measures to encourage PPPs, accepts that this involves the commodification of infrastructure via user-fees but puts in place cash transfers/universal basic income schemes to mitigate the potential exclusion of the poor from these services. That the derisking state does distributional politics through cash transfers paradoxically accommodates calls for rethinking welfare politics as wage labour becomes increasingly precarious (Ferguson, 2015). Ferguson's 'progressive' state is precisely the state that the WSC seeks to build: cash transfers would enable the poor to access commodified public services, and where these are not large enough, the state steps in to guarantee cash flows to investors.

Thus, development is not simply one-side defined by the political economy of capital (Nilsen, 2020), but more specifically, by financial capital seeking to expand to new areas, for which it colonises the infrastructure of the state. Financial capital no longer just drags the poor into the embrace of the market (Lavinas 2013, also Gabor and Brooks, 2017), but also the state. 
The infrastructural entanglement between the state and private finance goes back to the neoliberal insistence that central banks and Ministries of Finance become participants in financial markets in order to implement monetary and fiscal policies independently from each other (Braun, 2020a). As the wholesale (repo) money market and the government bond market became the governance infrastructure through which these two public actors seek to govern the macroeconomy, it generated "infrastructural power" for private financial institutions active in those markets. This entanglement becomes all the more dramatic when the state relies on private finance to fund and operate its physical and social infrastructure. Private finance, in its many guises, can leverage its infrastructural power not just to resist regulations but to entrench derisking as an accumulation regime.

The derisking state can thus be understood as a project that seeks to extend the infrastructural dependence of the state on finance - and thus the infrastructural power of the latter - from its two traditional domains of monetary and fiscal policy to other arenas of the government. The list is ambitiously long: water, housing, energy, health, education, transport, and even nature can be transformed in asset classes, a code for creating derisking partnerships.

Infrastructural power is most obvious where asset managers are directly involved in organising and running PPP projects. Take the French asset manager Meridiam. As of December 2020, its Meridiam Infrastructure Africa fund, with over EUR 500 million in assets, included a hospital in Ivory Coast, toll highways in Kenya, and renewable energy projects in Senegal, Ethiopia, Nigeria and Ivory Coast, all run as PPP projects. The key to its successful infrastructure fund, it argues, lies in its ability to strike derisking partnerships with African governments that transfer a broad range of risks, including currency risks, to the public balance sheet (Gabor and Sylla, 2020). This locks in hard currency revenues and profits for the asset manager, a critical risk transfer given that the currencies of commodity exporters - that is, most poor countries - are likely to experience persistent depreciation as climate regulations in high-income countries become more stringent (Kaphammer et al, 2020). But derisking is not just about the transfers of risks to the state. It is also about exercising infrastructural power to prevent (regulatory) risks from materialising. Asset managers' direct involvement in running 
PPP projects renders them important stakeholders in policy deliberations that relate to its infrastructure holdings (from health to energy, education or climate regulations etc).

In softer forms of infrastructural power, institutional investors purchase SDG/green bonds issued by actors involved in the construction of development asset classes, be them PPP operators or derisking state agencies. Additionally, derisking for these investors involves the central bank taking on its balance sheet bond liquidity and currency market risks.

The growing issuance of SDG bonds to finance state's derisking activities points to the importance of carefully scrutinizing the climate justice overtones of green infrastructure finance. Consider Morocco's embrace of green infrastructure finance as part of its turn to the Wall Street Consensus. Its urban housing and renewable energy policies rely on private-public partnerships, governed on the public side by two state agencies, Al Omrane in housing (Bogaert, 2018) and MASEN (Moroccan Agency for Solar Energy) in renewable energy. To finance their PPP derisking commitments (see Carafa et al., 2016 for the Noor Ouarzazate solar plant), both state agencies have issued green bonds in local currency, applauded internationally as path-breaking steps towards green infrastructure finance in Africa (Reuters 2016). Yet behind the techno-optimism of the Moroccan state's turn to derisking as development, critics identify the same neoliberal logic of the state facilitating wealth extraction while reproducing historical exclusions and inequalities in local communities (Aoui et al, 2020).

Beyond these broad contours, the Wall Street Consensus, like its predecessors, relies on a series of policy guidelines to reimagine development as derisking.

\section{THE TEN COMMANDMENTS OF THE WALL STREET CONSENSUS}

The Washington Consensus proposed 10 policy lines guided by the holy trinity of stabilization, privatization, and liberalization. These reimagined development for the international liberal order, shifting the overarching ambition from long-run productive transformations to a more efficient distribution of resources (Gore, 2000). A similar set of policies can be traced into the emerging WSC (see Table 1). 
Table 1: The 10 commandments of the Wall Street Consensus

\begin{tabular}{|c|c|}
\hline Washington Consensus & Wall Street Consensus \\
\hline $\begin{array}{l}\text { 1. Fiscal discipline, Central bank } \\
\text { independence }\end{array}$ & 1. Fiscal discipline, central bank independence \\
\hline $\begin{array}{l}\text { 2. Public spending: primary education, } \\
\text { primary health, public infrastructure }\end{array}$ & $\begin{array}{l}\text { 2. Public spending: de-risk new asset classes } \\
\text { 'Infrastructure as an asset class', 'Nature as an asset } \\
\text { class' }\end{array}$ \\
\hline $\begin{array}{l}\text { 3. Tax reform: lower marginal rate, broader } \\
\text { base }\end{array}$ & $\begin{array}{l}\text { 3. Sustainability reform: articulate Environmental, Social } \\
\text { and Governance ratings with SDG priorities }\end{array}$ \\
\hline $\begin{array}{l}\text { 4. Macro-finance policy: replace } \\
\text { developmental banking with market-based } \\
\text { interest rates }\end{array}$ & $\begin{array}{l}\text { 4. Sustainable local currency bond finance: engineer } \\
\text { market-based finance, prioritize securitization, support } \\
\text { securities prices (market-maker of last resort) }\end{array}$ \\
\hline $\begin{array}{l}\text { 5. Exchange rate: either market-determined } \\
\text { or 'competitive' according to equilibrium } \\
\text { theories, capital account liberalization }\end{array}$ & $\begin{array}{l}\text { 5. Hedging facilities and swapper of last resort to de-risk } \\
\text { currencies for (institutional) investors }\end{array}$ \\
\hline 6. Trade liberalization & 6. Financial globalization (no capital controls) \\
\hline 7. FDI promotion & 7. Portfolio flows promotion \\
\hline 8. Privatization & $\begin{array}{l}\text { 8. Privatization of pension funds for domestic resource } \\
\text { mobilization } \\
\text { (Privatization) PPPs for 'infrastructure as an asset class' }\end{array}$ \\
\hline 9. Competitiveness-enhancing deregulation & $\begin{array}{l}\text { 9. Policy derisking (removal of regulatory barriers to } \\
\text { PPPs and market-based finance) }\end{array}$ \\
\hline 10. Property rights & 10. Surveillance capitalism/Screen New Deal \\
\hline
\end{tabular}

\section{The fiscal-monetary architecture}

The WSC preserves the formal institutional macro-architecture of the Washington Consensus: an independent central bank targeting inflation and a Ministry of Finance/Treasury fiscally disciplined by bond markets. The separation matters in two ways. First, this macro-architecture preserves the 'infrastructural power' of private 
finance that relies on market-based forms of macroeconomic policy making (Braun 2020a). Second, the 'game of chicken' between an independent central bank and the Treasury keeps at bay a green developmentalist model that requires central banks to work closely with the developmentalist technocracy in charge of strategic industrial policy (Öniş, 1991), and to impose extensive capital controls in order to insulate the domestic financial system from global financial instability (Wade, 2018).

The focus on fiscal rectitude dictates the mechanisms for creating development asset classes: Public-Private Partnerships are framed as a strategic necessity (Bull and Milkian 2019, also Foster 2017, World Bank 2018a, p13). The PPP contracts specifies the distribution of risks between the public and the private sector, while the state's derisking commitments are recorded as contingent liabilities, and do not count as public debt. While PPPs are more expensive than traditional public investment, the illusion of fiscal effectiveness allows governments to circumvent budgetary restrictions (Bayliss and van Waeyenberge, 2018), often in the guise of progressive infrastructure policies, as 'affordable housing' PPP projects in Brazil and Colombia suggest (Santoro, 2019). To use Pistor (2019) lens, the legal battles to code capital into development asset classes requires the state to take risks from the private sector onto its balance sheet, in a clandestine reorienting of public resources that maintains the ideological commitment to 'fiscal responsibility'.

\section{Public spending: de-risking for institutional investors}

The Washington Consensus codified what Williamson (1993) described as 'belief in fiscal discipline' against 'left-wing believers in Keynesian stimulation via large budget deficits', a perspective that became 'almost an extinct species' in the 1990s. Fiscal discipline meant cuts to subsidies for state-owned companies and for basic consumption goods (e.g. gasoline, food). It prescribed spending on primary education, primary health rather than high-tech hospitals, and on public infrastructure investment. 
In contrast, The World Bank's operational tool, the Cascade Approach, stresses that scarce fiscal resources cannot deliver the $\mathrm{SDGs}^{6}$ (World Bank, 2017). It simplifies the UNDP recommendations into a three-step blueprint for producing investible asset classes: first policy derisking to improve the risk-return profile of investible projects, by for instance, allowing user fees on highways and encouraging capital markets development (see IMF and World Bank, 2020). Then, financial derisking in the form of subsidies and guarantees should ensure a steady cash flow for investors. Public investments should only be contemplated where derisking measures fail to produce investible development projects.

Figure 2 The Cascade Approach in the WB's Maximising Finance for Development

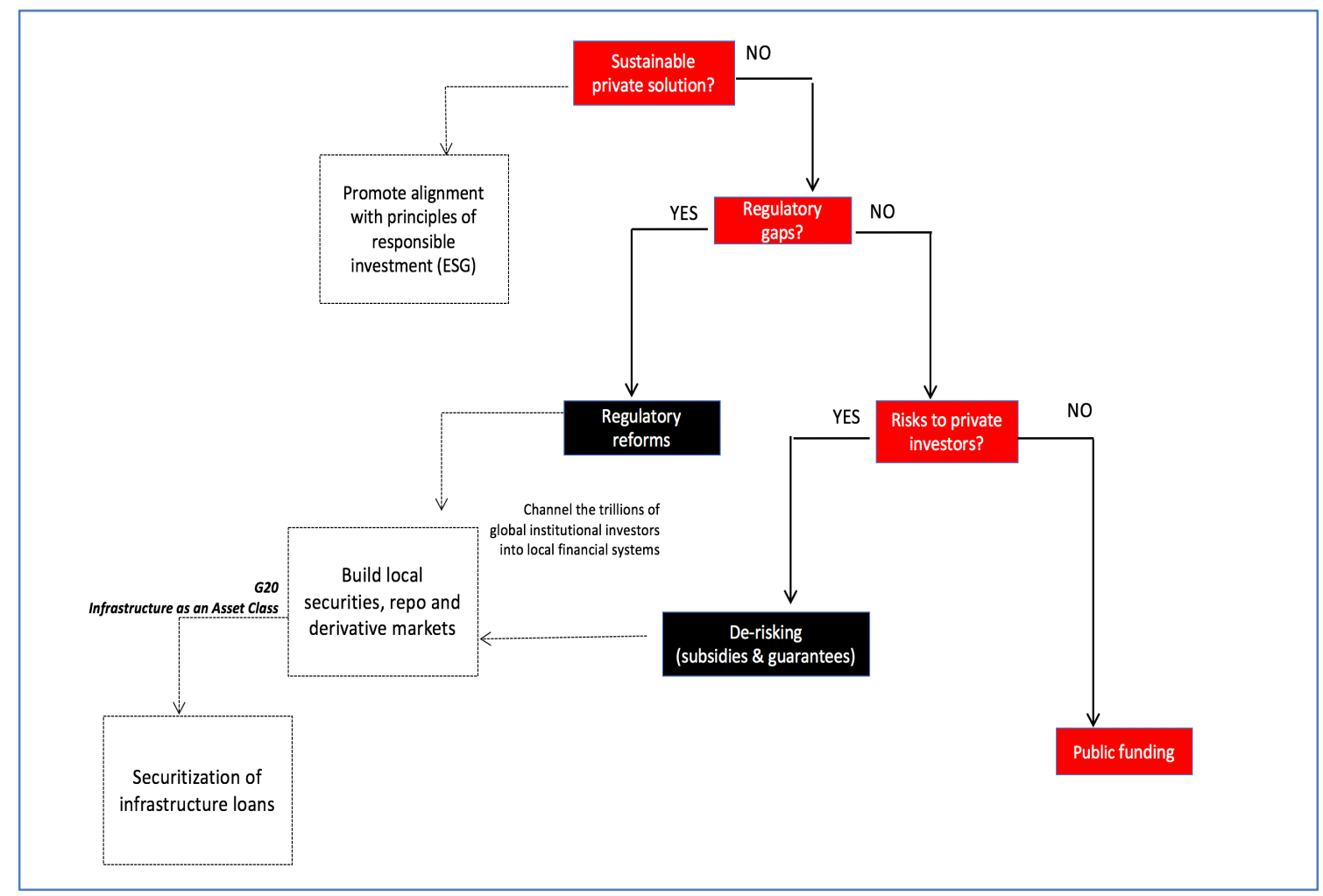

Source: Own representation of data from World Bank (2017)

The WSC incorporates lessons from the early 2000s on how to systemically enlist the state in de-risking infrastructure assets. Then, the privatization of urban infrastructure in high-income countries involved de-risking via complex financial instruments, and global interlinking in the portfolio of global institutional investors (Pryke and Allen,

\footnotetext{
${ }^{6}$ The World Bank's (2018a) InfraSAP for Vietnam claims that the existing model for financing energy infrastructure - state lending to state companies - is no longer viable because of statutory public debt limits.
} 
2017). Yet local political contestation of contract terms often threatened cash flows (Morag Torrance, 2008). Where new asset classes involve uncertain flows of value, Carruthers and Stinchcombe (1999) argued, the state can generate predictability by first rendering assets knowable and then 'deriskable'. In the US, state agencies Fannie Mae and Freddie Mac assembled mortgage loans for delivery to shadow banks, which in turn resorted to securitization in order to create tranches with different risk profiles.

But the WSC has bigger ambitions for the state, beyond creating the conditions for private derisking via complex financial instruments. It constructs a broad range of public risk-proofing strategies of development assets, as can be gleaned from the InfraSAPs for Egypt, Nepal, Vietnam and Sri Lanka produced by the World Bank until 2020 (World Bank 2018a,b; 2019a,b).

The WSC state assumes demand risk in user-fee based (social) infrastructure and political risk that future governments might (re-)nationalize commodified infrastructure or introduce tighter regulations, ranging from labour laws to climate regulations that would affect profitability.

Demand risks are a critical feature of PPP-based development asset classes. As with any commodity, should demand for PPP services fall, it threatens profitability, and the cash flows to service the bonds issued by PPP providers to private investors. This can occur when users cannot afford the fees for accessing PPP infrastructure. To derisk such projects, to render them 'investible', the state assumes demand risk: it guarantees, via PPP contracts, a certain level of demand. For instance, the World Bank (2018a) Egypt InfraSAP advises that PPP contracts should include Payment Security Mechanisms that guarantee payment flows against low demand. In the Vietnam InfraSAP, the World Bank applauds the PPP law that moves onto the public balance sheet: offtake ${ }^{7}$ risks for private energy producers, currency convertibility and inflation adjustment, and termination payment obligations, across 'transportation; street lighting; water supply; waste treatment; power plants and transmission; commercial

\footnotetext{
${ }^{7}$ In poor countries, the standard institutional arrangement in power infrastructure relies on a state-owned utility as the main project counterparty responsible for purchasing the power output produced by PPP companies, at a pre-agreed price. The offtake risks are those risks of not getting paid for output.
} 
infrastructure; social infrastructure facilities for health care, culture, sports, industry, and agriculture' (World Bank, 2018b: 23). The Sri Lankan InfraSAP (WB and IFC, 2019) advises the state to pass the costs of de-risking to end-users via periodic adjustments of tariffs, and in case of severe disruptive events, to absorb those costs ( $p$. $63)$.

Figure 3 InfraSAPs recommendations: the Cascade Approach in practice

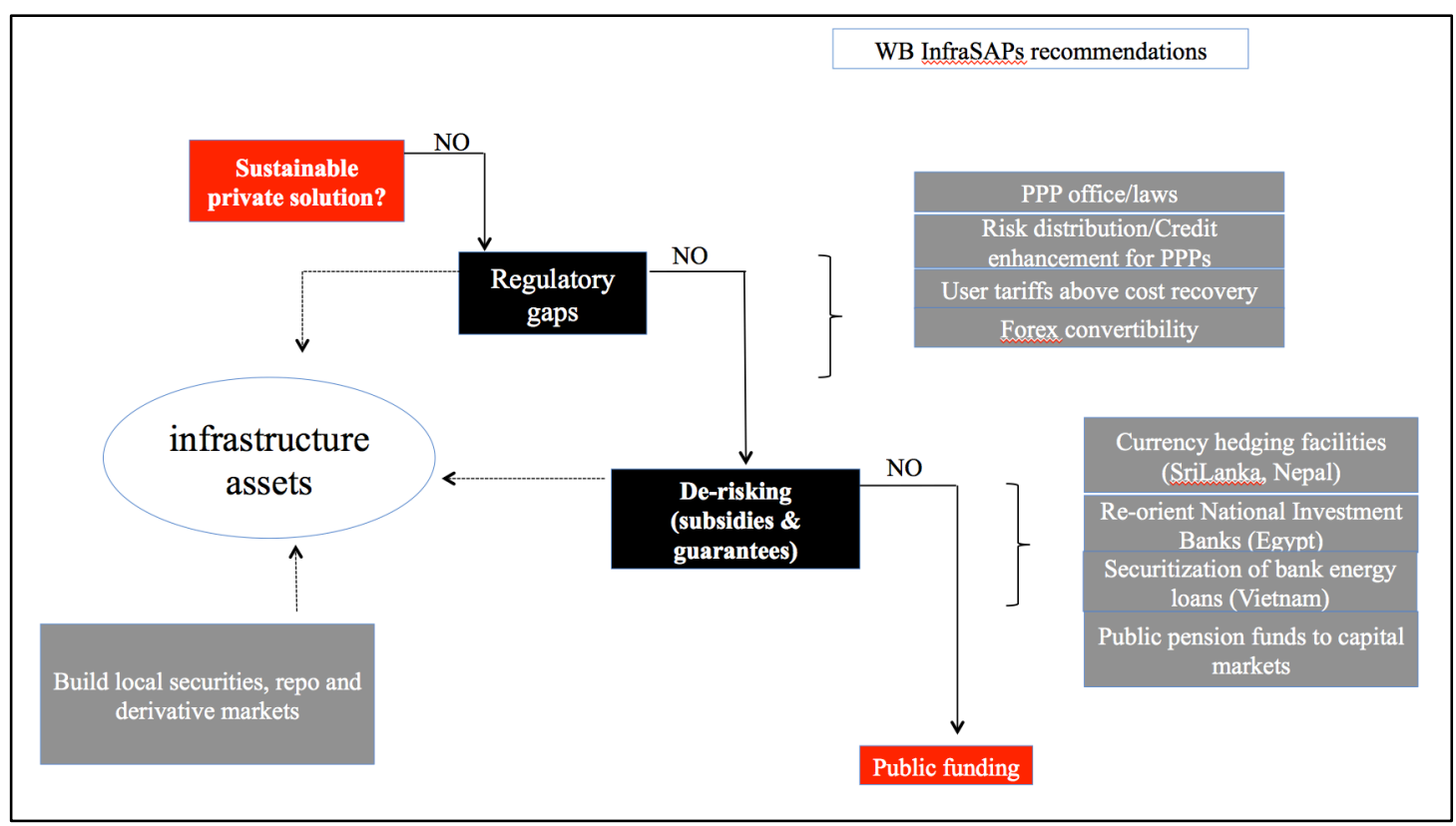

Source: Own representation of data from WB InfraSAPs.

The fiscal costs of demand de-risking can be significant. Take Nigeria and Ghana. At the World Bank's Maximizing finance for the development of infrastructure in Nigeria workshop in September 2019, the Minister of Finance noted that 'Nigeria no doubt lacks the fiscal space to self-finance' the estimated USD100 billion a year infrastructure gap. Instead, she promised to continue its collaboration with the World Bank to leverage private finance, building on previous success stories in 'transport, energy and power sectors using PPP models' ${ }^{8}$. Among those, the World Bank representative identified the Azura power plant 'as an example of how we have attracted private sector investment in the power sector', the first privately-financed power project in Nigeria. But the de-risking template for 'lighting up Africa' ${ }^{9}$ is hardly a success story. The

\footnotetext{
$8 \quad$ See $\quad \underline{\text { https://nairametrics.com/2019/09/24/nigeria-needs-100-billion-annually-to-fix- }}$ infrastructural-deficit-finance-minister/

9 https://www.institutionalinvestor.com/article/b14z9q8pv7zzdb/is-new-nigerian-powerplant-a-template-for-lighting-up-africa
} 
contract committed state-owned Nigeria Bulk Electricity Trading to buy Azura's output, although it quickly turned out that Azura's installed capacity could not be absorbed by the dilapidated Nigerian grid energy infrastructure. As the state-owned company became unable to pay Azura in full, the World Bank threatened to trigger the partial risk guarantee it had put in the project to reassure international investors. Eventually, the central bank compensated Azura from a special fund intended to derisk other private energy producers. Nigeria had little choice, since a triggered World Bank risk guarantee becomes a loan to Nigeria (the de-risking state always pays!) ${ }^{10}$. In turn, the World Bank conditioned the disbursement of a USD 1bn loan on Nigeria agreeing to structural reform in the energy sector "critical for de-risking the sector for private investments". Blended finance, that is the use of public development finance from the World Bank to leverage private finance, doubled down as a disciplinary instrument to force restructuring (read privatization) of the Nigerian energy sector.

Ghana's experience with PPP energy projects, also backed by the World Bank, is similar. Its PPP contract for the exploitation of Sankofa offshore gas involves a 'take or pay' clause that obliges the Ghana National Petroleum Corporation to purchase $90 \%$ of a predetermined quantity of gas, whether it can use it or not. Predictably, Ghana's 'derisking as development' strategy applied to the energy sector via take-or-pay contracts left it paying 'about US\$500 million annually for power generation capacity that it does not use' (around $0.7 \%$ GDP) and its energy sector a 'significant fiscal risk' for the budget (IMF, 2019). Similarly, the IMF's 2019 report on Fiscal Transparency in Senegal calls into question both the creation of long-term liabilities for the state, and the absence of a framework to monitor the fiscal costs of derisking PPPs (see Gabor and Sylla, 2020). While Senegal's case is the rule across countries that have embraced PPPs, there are noteworthy exceptions. For instance, Uruguay's PPP law, passed by the Mujica government in 2011, caps the total direct and contingent liabilities generated by PPPs for the state to 7\% of the previous year's GDP, and fiscal transfers to private operators to $0.5 \%$ of previous year's GDP (Government of Uruguay, 2011).

$10 \mathrm{https} / /$ uk.reuters.com/article/uk-nigeria-power-exclusive/exclusive-nigerian-energysectors-crippling-debts-delay-next-power-plant-idUKKCN1OK1J4. While the ensuing scandal prompted the government to suspend other PPP initiatives, the September event suggests continued political commitment to the Wall Street Consensus. 
The fiscal costs of protecting investors from demand volatility will rise rapidly as extreme climate events accelerate. Indeed, the climate crisis creates political and demand risks that institutional investors need de-risking for.

\section{Sustainability reform: the turn to ESG ratings}

The $2011 \mathrm{DB} / \mathrm{UNDP}$ report on renewable energy was written at a time when green bonds were a niche area for impact investors. By 2020, as public demands for climate policies grew rapidly, green finance moved into mainstream investment practice through the framework of Environmental, Social and Governance (ESG) ratings, a private sector approach that, it is increasingly argued, could be guided by the SDGs ${ }^{11}$.

The ESG ratings started as a corporation-focused, equity-tailored system of encouraging corporations to systematically disclose data that capture their environmental, social and governance practices. These would eventually be aggregated into a rating or score, and extended from equity to bonds/securities, including those issued by countries (Inderst and Stuart, 2018). Thus, the ESG framework is morphing into a private taxonomy for green/dirty ${ }^{12}$ finance: high ESG ratings are interpreted to signal 'green' financial instruments, and vice-versa.

Institutional investors turned to ESG ratings as a strategic tool to acquire infrastructural power in both 'development as derisking' and climate policy spaces.

First, some institutional investors have developed in-house capacities to develop ESG criteria that map onto the Sustainable Development Goals. For instance, Meridiam, the French asset manager with one of the largest portfolio of African infrastructure investments, complements its ESG risk practices with an SDG evaluation framework, to capture 'the positive contribution of projects on issues such as health, education, water, sanitation, energy, urbanization, environment and social justice'. While it

$11 \mathrm{https} / /$ www.pimco.co.uk/en-gb/insights/viewpoints/esg-investing-and-fixed-income-thenext-new-normal/

12 the standard climate finance language distinguishes between green and 'brown' assets, disregarding the racist connotations embedded in conceptualizing dirty finance as 'brown' (see https://www.commondreams.org/views/2020/06/26/language-brown-finance-climate-financeracist).. 
impossible to evaluate such claims, since proprietary tools are not transparent, the articulation of ESG and SDG allows institutional investors to become credible development partners to the de-risking state and multilateral development banks. Such new partnerships are emerging rapidly. The Asian Infrastructure Investment Bank's Asia ESG Enhanced Credit Managed Portfolio ${ }^{13}$ (AIIB, 2019: 3) delegates ESG rule making and enforcement to private finance. The World Bank's updated Environmental and Social Framework ${ }^{14}$ similarly embraces the ESG status-quo. Long seen as 'gold standard in development finance ${ }^{15}$, it replaces mandatory safeguards with a 'riskbased, outcome focused, tailored and proportionate approach'. The World Bank accepts the use of borrowers' environmental and social frameworks that are 'materially' close to the WB's own, without clearly defining either 'materially close' or mechanisms for monitoring changes in borrowers' frameworks ${ }^{16}$.

Yet private taxonomies are dubious in their promise of 'developmental outcomes'. ESG providers often use bespoke screening to eliminate companies or countries whose business lines are inconsistent with certain investment policies. For instance, the financial service firm MSCI provides bespoke screening for 'Catholic values' like antiabortion legislation ${ }^{17}$. Investors can claim developmental outcomes when their investment decisions actively undermine women's rights agendas.

Second, investors strive to become the epistemic guardians of green taxonomies. By controlling the grammar of green finance, they can apply the 'green' or 'sustainable' label to asset classes that have a negative environmental impact, a greenwashing exercise that effectively waters down climate regulations in order to protect profits. The climate politics of the Wall Street Consensus thus reaches beyond that of green

\footnotetext{
${ }^{13} \mathrm{https}$ //www.aiib.org/en/projects/approved/2018/_download/regional/ESG-enhanced-creditmanaged-portfolio.pdf 14 Other MDBs use a similar framework, with varying degrees of credible commitment to the E\&S principles (see for example https://thediplomat.com/2017/08/is-the-aiib-really-leanclean-and-green/ for AIIB)

15 http://archive.bankinformationcenter.org/world-banks-updated-safeguards-a-missedopportunity-to-raise-the-bar-for-development-policy/

${ }^{16}$ https://consultations.worldbank.org/Data/hub/files/oxfam_comments_on_second_draft_wb_ environmental_and_social_framework.pdf

17 http://documents.worldbank.org/curated/en/913961524150628959/pdf/125442-REPLPUBLIC-Incorporating-ESG-Factors-into-Fixed-Income-Investment-Final-April26-

LowRes.pdf
} 
infrastructure finance discussed above, because it targets the entire universe of financial instruments through which credit is created, rather than the subset financing sustainable activities.

In doing so, investors are strategically adjusting to central banks' turn to climate policies (Dafermos et al, 2020a). Before the COVID19 shock, central banks in the Network for Greening the Financial System had argued that climate risks were financial stability risks, and began the process of designing a climate regulatory regime that seeks to apply the (shades of) green/dirty lens to the entire universe of assets -- bonds, loans, equity - held by banks, institutional investors and asset managers. The aim is to reorient credit from dirty to green activities, and in the process, reduce both the impact of extreme climate events on financial actors, and the contribution that the financial system makes to the climate crisis by financing high-carbon activities.

Carbon financiers seek to resist this new form of credit controls. By constructing ESG taxonomies as an alternative to public taxonomies ${ }^{18}$, financiers can deploy their ESG expertise to greenwash their own portfolios ${ }^{19}$, public taxonomies and regulatory regimes, as Blackrock, the world's largest asset manager, has set to do in the European Union. Indeed, beyond infrastructural entanglements, a private ESG regime enables green regulatory arbitrage. Investors can shop across around for high ESG ratings for their portfolios, given that ESG providers quantify ESG performance on a large number of criteria, chosen and assessed on discretionary basis, resulting in conflicting ratings/score ${ }^{20}$. Conversely, weak ESG standards perpetuate greenwashing understood as the failure of financial markets to price climate risks adequately.

It is critical to note that the Wall Street Consensus creates mechanisms through which investors transfer the potential costs arising from their greenwashing to the state. One

18 The European Commission's Sustainable Finance taxonomy is one such example, subjected to heavy lobbying from private financial institutions in order to expand the definition of green (see Gabor 2020b).

${ }^{19}$ Blackrock offers ESG passive investment vehicles (ETFs) that include fossil fuel companies, while wielding its shareholder power to block climate measures against high-carbon companies https://bit.ly/2zzTZ5f

20 Tesla's global auto ESG ratings vary from very good to very bad, depending on providers, see https://ftalphaville.ft.com/2018/12/06/1544076001000/Lies--damned-lies-and-ESGrating-methodologies/ 
mechanism, detailed above, ensures that the state compensates PPP investors and operators for falls in demand caused by extreme climate events. SDG-led development thus becomes a strategy of green financialisation through which private finance manages the environmental crisis, a step further in the financialization of nature that once focused on risk instruments such as catastrophe bonds (Keucheyan, 2018).

The WSC protects investors against the political risks associated with green developmental states. The green developmental state would prioritise the reorientation of finance towards low-carbon activities. This requires a public taxonomy of green/dirty assets that overcomes the shortcomings of private ESG ratings, and policies to penalize dirty assets (through capital requirements or haircuts) ${ }^{21}$. Yet in the Wall Street Consensus framework, such policies would classify as political risks, and require the state to compensate their holders.

In its strategy to mutate climate risks into political and demand risks, private finance may have found an important ally. Central banks conceptualize the immediate impact of tighter climate rules regulation that increase the cost of funding or dramatically change asset values as transition risks (Christophers, 2019) ${ }^{22}$. The faster the low-carbon transition, it is argued, the higher the potential that transition risks affect financial stability, thus binding central banks in political trade-offs that privilege incremental green regulatory regimes and accommodate greenwahing, however urgent the climate crisis. Indeed, when central banks prioritize transition risks, they effectively rely on private finance to drive the climate agenda, with their coordinating role focused on subsidizing green assets, via so-called 'green quantitative easing' (Bolton et al, 2020).

In seeking to enlist central banks in the political coalitions against biting climate regulation, the Wall Street Consensus constrains the green developmental states directly, by making it liable for transition risks that can be framed as political and

21 Such initiatives already exist. The European Commission announced a public 'green' (or sustainable) taxonomy in June 2019 that it expects to become the benchmark for European finance. It however encountered fierce opposition to its plans to develop a dirty assets taxonomy.

https://ec.europa.eu/info/business-economy-euro/banking-and-finance/sustainable-finance_en 22 See https://www.bankofengland.co.uk/knowledgebank/climate-change-what-are-the-risksto-financial-stability 
demand risks, and indirectly, by reducing the public resources and central bank support for Green New Deal programs that can effectively manage transition risks. The derisking state and the green developmental state can hardly co-exist, particularly within market-based financial structures.

\section{Derisking market-based finance (formerly known as shadow banking)}

The turn to private finance as vehicle for sustainable development requires a change in financial structures to accommodate the portfolio glut. It makes shadow banking, understood as the production (via securitization) and financing (via wholesale funding and derivative markets) of tradable securities, the desirable structure for financial systems across the Global South (Musthaq, 2020). Indeed, the WSC consolidates several global initiatives to restructure bank-based financial systems into market-based finance or shadow banking (see Figure 3, IMF and World Bank, 2020; Gabor, 2018), where institutional investors can easily purchase local bonds (securities), including infrastructure-backed securities, and finance as well as hedge their securities positions via repos and derivative markets. Structural policies shift from developmental states' concern with the productive structure (Wade, 2018), to the financial system.

Through subtle norm substitution, in the tradition of the Washington Consensus (Kentikelenis and Babb, 2019), the organizations behind the Wall Street Consensus have sought to normalize the appropriateness of a market-based financial structure in technocratic forums away from public scrutiny. Thus, the Local Currency Bond Market Initiative seeks to put in place the 'plumbing' of securities markets - derivatives and repo markets - that would improve their liquidity (Gabor, 2018). This would reduce both poor countries' reliance on foreign currency debt and their funding costs in local currency markets. Originally introduced under the 2007 German leadership of the G8, in cooperation with the World Bank and the IMF, the initiative called for the privatization of pension funds and the promotion of 'mutual funds and insurance companies' to increase domestic resource mobilization. In parallel and overlapping, the Financial Stability Board announced in 2015 that its new priority would be to transform shadow banking into resilient market-based finance, which it defined as securities, derivatives and repo markets. In sum, the organizational promoters of the Wall Street 
Consensus championed in a multiplicity of global regulatory spaces the idea that financial structure change is critical to attract the portfolio glut.

Figure 4 The turn to securities markets/market-based finance in international development

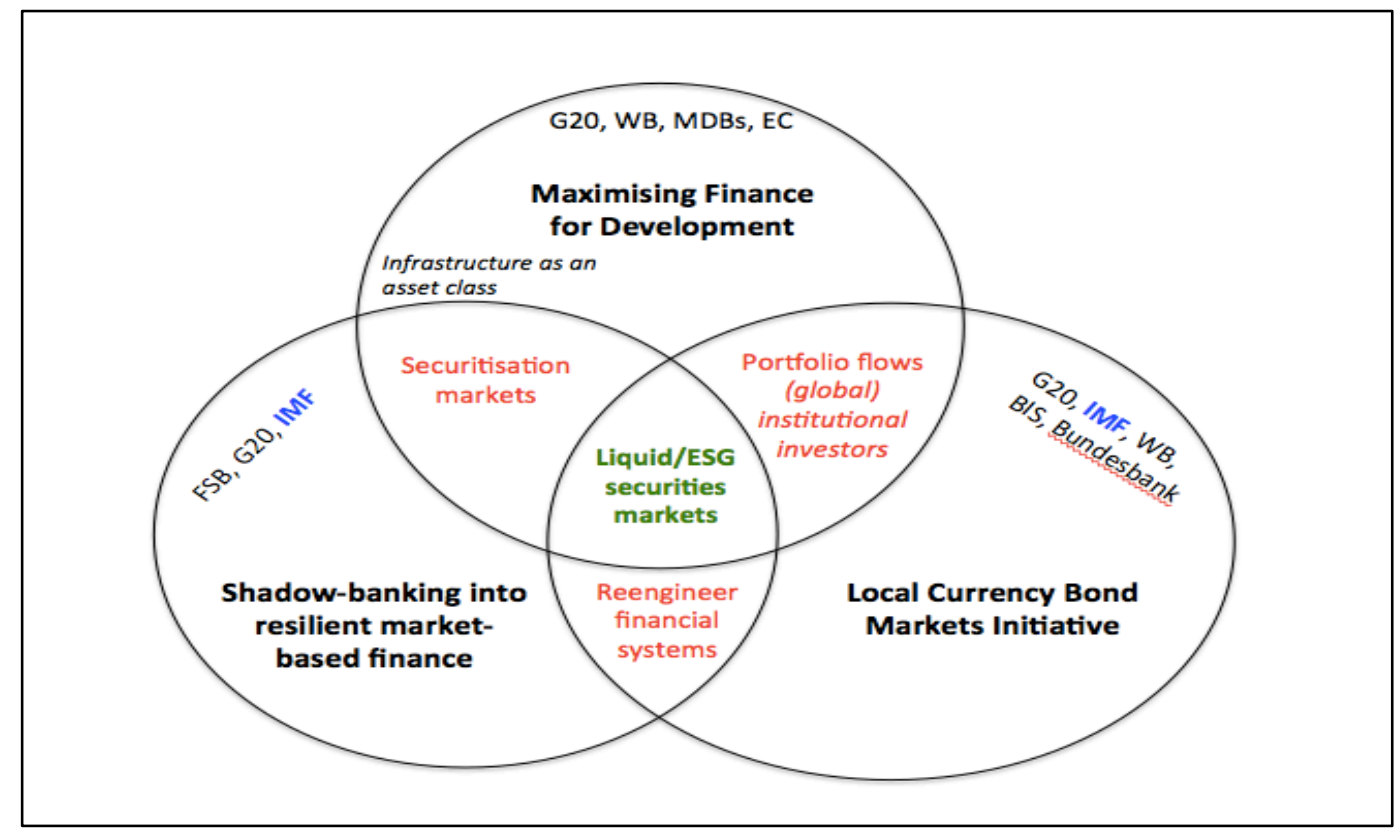

Source: own representation.

The push for market-based finance aims to rescue securitization from the disrepute it fell into after the collapse of Lehman Brothers. The OECD's low-carbon infrastructure push, the MDBs plans to optimize balance sheets, or the G20 plans ${ }^{23}$ for Infrastructure as an Asset Class promote securitization, shadow-banking instrument par excellence, a de-risking instrument that can attract institutional investors (Gabor, 2019). The securitization of infrastructure loans would create both highly rated, low-return tranches suitable for conservative pension funds/asset managers and lower-rated, higher return tranches suitable for risk-driven investors. It would also accelerate lending to infrastructure projects, constrained by Basel III rules for banks. As the Vietnam InfraSAP suggests, bank energy loans could be securitized to make room for additional lending (World, Bank 2018a). Banks could also sell infrastructure loans to platforms such as the AIIB's Infrastructure Private Capital Mobilization Platform, which in turn would package and securitize them for distribution through capital markets to 'build

\footnotetext{
23 See the Eminent Persons Group proposals to the G20 https://g20.org/sites/default/files/media/epg_chairs_update_for_the_g20_fmcbgs_meeting_in _buenos_aires_march_2018.pdf
} 
infrastructure as an asset class' (AIIB, 2019:1). The African Development Bank's 2019 synthetic securitisation deal, known as Room2Run, was greeted as a groundbreaking initiative that illustrates how MDBs can harness the power of financial innovation to create new development asset classes on the African continent (Gabor, 2019).

Since market-based finance is more systemically vulnerable than traditional bank-based systems, the Wall Street Consensus assigns a triple de-risking role to central banks: in bond markets and currency markets as market-makers of last resort (Musthaq, 2020), and, forced by the inevitable consequences of green washing, as climate rescuers of last resort, for assets left devalued by extreme climate events (Bolton et al, 2020). Critically, the politics of central bank derisking varies across asset classes. Some derisking interventions, particularly in government bond markets, are at odds with the ideological premises of central bank independence. Thus, the process of implicating central banks in upholding the institutional basis of the derisking-centred accumulation regime is incremental. It builds on crises such as the COVID19 pandemic to normalize new derisking practices.

Before the COVID19 pandemic, the WSC institutions agreed on currency derisking. Currency risk has long been identified as a significant obstacle to attracting foreign institutional investors in large-scale infrastructure assets (Baker, 2015). The attention paid to currency derisking reflects the macrofinancial politics of the turn to the portfolio glut. The G20 push for local currency bond markets reflects the familiar concerns with the systemic vulnerabilities hardwired into poor and middle-income countries' reliance on dollar debt. Yet, in rejecting capital controls, it fails to grapple with the fundamental insight that foreign demand for local currency assets in the form of portfolio flows continue to expose countries, and their currencies, to the volatilities of the global financial cycle (Rey 2015, Gevorkyan and Kvangraven, 2016). Indeed, elsewhere the IMF recognizes that local securities and equity markets, capital flows and credit cycles increasingly move together, all in the shadow of the US dollar (Adrian, 2019). Increasingly popular Exchange Traded Funds (ETFs) - that package equities or bonds issued in emerging countries and issue ETF shares against them - sharpen dollar dependency. ETF issuance and redemption requires the purchase/sale of the underlying shares/bonds, thus amplifying the global financial cycle (Converse et al, 2020). In sum, borrowing in local currency from foreign portfolio investors, directly or via ETFs, 
offers no magical solution to countries' subordination in a hierarchical international monetary system. It leaves them exposed to dollar financing conditions, while exchange rate volatility amplifies portfolio flow pro-cyclicality: currency depreciation accelerates capital flight (Hördahl and Shim, 2020).

In response, the WSC outlines three currency-derisking approaches. State institutions, such as state development banks, provide hedging facilities through which institutional investors and asset managers transfer currency risks in PPP contracts to the state (World Bank 2018a,b). Currency derisking is ubiquitous in PPP contracts, to ensure that the profits of private PPP operators can be converted into dollars or euros and repatriated at a pre-agreed exchange rate (Gabor and Sylla, 2020). This further adds to pressures on local currencies, particularly for countries with trade balances structurally in deficit. Second, central banks can undertake regular derivative operations to derisk exchange rates for foreign holders of local currency bonds (Macalos, 2017). Finally, central banks can become swappers of last resort, supplying financial institutions with foreign liquidity during periods of instability, thus reducing exchange rate volatility (Gonzales et al, 2019). While these WSC-aligned new practices were at first adopted by a handful of central banks in middle-income countries, the COVID19 pandemic paved the way for their normalization across the Global South as the US Federal Reserve scaled-up its role of global dollar lender of last resort, albeit in a geopolitically strategic manner (Dutt, 2020). The US Federal Reserve extended its USD dollar liquidity provision in a two-tier hierarchy of central banks: swaps with 'peers', including several large emerging countries, and repos with other central banks that the Fed treats as private commercial banks, who can borrow against their US Treasuries portfolios. With this, the US Fed strengthened the institutional basis for currency derisking across countries in the Global South.

Equally important, the COVID19 pandemic upended the taboo around derisking government bonds in middle-income countries, enduring there as a legacy of the Washington Consensus view that central bank interventions in government bond markets amount to their pathological capture by populist governments. Central banks in Indonesia, Colombia or South Africa purchased government bonds to support liquidity and to preserve their attractiveness for nervous institutional investors. This 
matters because market-based finance creates distinctive liquidity pressures in bond markets that can rapidly explode into financial crises.

The WSC template for liquid securities markets calls for putting in place the fragile plumbing of US financial markets. This 'Americanization' envisages a market-based financial system where repo and derivative markets lubricate the liquidity of securities markets by enabling institutional investors and banks to deploy them as collateral in financial transactions. It requires the creation of repo markets where these are missing, or their liberalization, to enable legal transfer of title to collateral securities, to allow mark to market of collateral and shorting, and the development of onshore derivative markets (Gabor, 2020). Yet it was precisely this type of collateral-based financing markets that fed, through shadow banking, cycles of liquidity and leverage before Lehman. When the crisis came, it manifested in fire sales of securities, evaporating collateral liquidity and runs on collateral-based funding markets (Brunnermeier and Pedersen, 2009). While the Financial Stability Board recognized the systemic nature of shadow markets like the repo market, the new rules do not go far enough to contain the destabilizing dynamics (Gabor, 2018). This is why central banks in high-income countries adopted a new bond market-maker of last resort function after the collapse of Lehman Brothers. Central banks derisk repo markets by directly purchasing bonds that are an important source of collateral for market-based finance, in particular government bond markets (Mehrling, 2012; Gabor, 2016). Put differently, central banks take the risk of collateral securities' liquidity on their balance sheet. In so doing, they stabilize the plumbing of market-based finance, preserving banks' and investors' ability to tap collateralized funding markets, and to exit bond markets without large losses. Government bond purchases may look to some as debt monetization, but in marketbased finance, such measures are driven by financial stability (derisking for bondholders), not fiscal considerations (derisking for the sovereign). Central banks can accommodate the fiscal spillovers by arguing that since they dictate the terms on which they derisk government bonds, and they intervene for prudential rather than fiscal reasons, their independence remains sacrosanct (Gabor, 2020).

The project of enlisting central banks in the institutional architecture of derisking goes further. In a future when the consequences of systemic greenwashing start to manifest on the balance sheet of institutional investors and asset managers, central banks could 
become climate rescuers of last resort (Bolton et al, 2020). Greenwashing, like any other regulatory arbitrage, eventually confronts its architects with the systemic problems it feeds - extreme climate events will devalue carbon-intensive assets and greenwashed assets. The political logic of the Wall Street Consensus calls for central banks to rescue the holders of last resort for carbon-intensive assets (Jahnke, 2019), to risk-proof their portfolios, taking on its balance sheet the consequences of systemic greenwashing.

The multiplicity of de-risking roles envisaged for central banks are not surprising. Rather, these reflect institutional complexity underpinning the process of transforming development projects into asset classes. As Klagge and Nweke-Eze (2020) document, complex risk structures deterred institutional investors from participating in Keyna's renewable energy projects, leaving MDBs, governments and renewable industry investors to finance and derisk. Thus, the derisking of PPP infrastructure and its financing via securities sold to institutional investors may proceed at different pace, constrained by the pace of structural transformation of local financial systems and the (internal) politics constraining central bank interventions.

\section{Surveillance capitalism in the WSC}

Finally, WSC aims to leverage the model of surveillance capitalism (Zubhoff, 2019) already deployed via the trope of digital financial inclusion in overlapping networks of state institutions, international development organisations and 'philanthropic investment' fintech companies (Gabor and Brooks, 2017). The aim was to map, harvest and monetize digital footprints via behavioural analytics to render the poor 'investible' through an 'all data is credit data' approach.

Surveillance capitalism increasingly overlaps with the Wall Street Consensus, as illustrated by the turn to private/PPP healthcare in African countries. In the wake of the Washington Consensus, African countries privatized health through different methods, from user fees on public health services to encouraging private healthcare and promoting insurance schemes (Baloyi, 2019). Across SubSaharan Africa, 50\% of healthcare is provided by the private sector, with financing provided by investment platforms and fund managers promoting the development of healthcare asset classes 
(Hunter and Murray, 2019). Enter digital healthcare, with its promise of better diagnostics through advanced technologies, and a complex ecosystem ripe for 'health as an asset class' initiatives.

PharmAccess Group, for instance, operates both on the supply side and the demand side of private healthcare. It provides financing to small-scale private health companies in Tanzania, Kenya, Ghana and Nigeria, from healthcare SMEs to specialist care providers and other businesses catering to health facilities, through the Medical Credit Fund. PharmAccess' partners include AfDB, the World Bank and most official development aid agencies, alongside foundation involved in the financial inclusion project. On the demand side, it has received ODA funding for the Safaricom-backed healthcare app M-Tiba, where users save for medical care, pay and manage their insurance policies and support their dependents.

Digital healthcare can morph into surveillance devices whereby insurance companies can adjust premiums via data delivered to doctors. For instance, MTiba launched a new hypertension and care app for low-income patients in 2018, that allows them to monitor blood pressure and blood glucose levels, digitally sending the results to doctors for review. Combined with digital awareness and self-management support through the innovative app called Afya Pap, this integrated approach aims to increase symptom recognition and treatment adherence. M-Tiba thus functions as an entry point for institutional investors like insurance companies, who can get new markets for their products, and others who can securitize healthcare loans.

The surveillance capitalism elements of the WSC saw in the COVID19 pandemic a strategic opportunity. US fintech companies began advocating a 'Screen New Deal' that promotes public-private partnerships in $\mathrm{AI}$ in order to strengthen the private digital provision of public goods, including education, health, and infrastructure (Klein, 2020).

\section{THE COVID GLOBAL PANDEMIC: THE GRAND DEVELOPMENT BARGAIN WITH PRIVATE FINANCE}

The global COVID19 pandemic saw a scaling-up of derisking as a governance tool. The new conceptual amour for state intervention was deployed more forcefully in high- 
income countries, where central banks' accelerated their market-making activities to prop up public and private securities, and Ministries of Finance entered de-facto publicprivate partnership by assuming risks on bank loans and private-sector wages. Rising public debt across poor and emerging countries, the global push for green recoveries and central banks' turn to derisking currencies and sovereign bonds via unconventional liquidity operations combined to increase the attractiveness of the WSC paradigm (see Dimakou et al, 2020). The WSC took a distinctive climate turn, Dafermos et al (2020b) argue, to advocate for climate infrastructure as an asset class, climate rescuer of last resort, disclosure of climate-related financial risks and carbon pricing.

Furthermore, the push for Americanised financial systems maintained its pace. In April 2020, Frontclear, a financial markets development institution financed by official development assistance to 'create more stable and inclusive interbank markets in emerging and frontier markets' announced that it would guarantee repos with local bonds as collateral as an important stepping stone towards a fully-functioning repo market, greater liquidity and therefore greater foreign investor presence across emerging and low-income countries (Euroclear, 202024). Related, the United Nation's Economic Commission for Africa proposed a Liquidity and Sustainability Facility that would to subsidise investor demand for African sovereign debt via a special repo instrument (ECA, 2020).

Yet the COVID19 pandemic illustrates starkly the limits of the public-private finance partnership for achieving the SDG. When the G20-Paris Club agreed the Debt Service Suspension Initiative (DSSI) in April 2020, it had hoped that the holders of Eurobonds (foreign currency bonds issued by poor countries) would voluntarily join official creditors in the suspension of payments.

Bondholder resisted calls for involvement through a stick and two carrots strategy. The Institute of International Finance (IIF, 2020), a powerful lobby group for private finance, argued in a public letter to the G20 that poor countries would be jeopardising their hard-won access to international bond markets by supporting mandatory private-

\footnotetext{
${ }^{24} \mathrm{https} / / /$ www.euroclear.com/newsandinsights/en/Format/Articles/emerging-marketilliquidity.html?cid $=$ TW1119\&utm_medium $=$ social\&utm_source $=$ twitter\&utm_campaign $=$ po stfity\&utm_content $=$ postfitya0c42
} 
sector involvement in the DSSI. Indeed, around 30 DSSI-eligible countries - some at high risk of debt distress, such as Ghana and Kenya - chose to not apply to the DSSI in order to preserve market access. The IIF also warned the G20 that emerging countries could also see significant capital outflows and/or higher interest rates.

Instead, the IIF letter promises two carrots from the Wall Street Consensus repertoire: the SDG funding gap and the growing mainstreaming of ESG concerns in institutional portfolios. The SDG funding gap, the argument goes, cannot be closed without private finance. The trillions of dollars held by institutional investors could find their way into local currency SDG bonds to finance education, health, roads, electricity, water, and sanitation in poor and emerging countries. The second carrot highlights the Covid-19 pandemic as a watershed moment for investors to mainstream sustainability in their portfolios. The incoming ESG tsunami, the IIF letter argues, would shower poor countries with (sovereign bond) market liquidity, as long as there are no barriers to entry, such as mandatory participation in an extended DSSI.

The IIF letter serves as a reminder that the success of the Wall Street Consensus should not simply be judged on the empirical grounds of how much private finance it successfully leverages into development asset classes. On those grounds, ambitions are still far ahead of reality, in part because this young political project aims to both fundamentally reconfigure state institutions and create infrastructural power for private finance in order to create the institutional basis for accumulation organized around development asset classes. Such a process takes time and is ridden with political and institutional complexity. More important, the WSC has already forged a powerful development narrative that constrains the actions of states and multilateral development institutions. By continuing to service the debt held by private finance 'partners', poor countries have chosen to prioritise social pain at the height of a pandemic for the elusive promise of SDG-related inflows, on commercial terms and into user-fee-based public services, sometimes later. This is an important marker of the success of the new 'development aid is dead, long-live private finance!' development paradigm. 


\section{Conclusion}

The Wall Street Consensus re-imagines international development interventions as opportunities for global finance. In the new 'development as derisking' paradigm, institutional investors and asset managers are able to influence, if not altogether shape, the terms on which poor countries join the global supply of 'SDG' securities. Multilateral development banks lead the efforts to design the "de-risking"/subsidies measures that seek to protect global investors from political risk or the demand risk associated with privatized public services.

Equally important, this is a state-building project that puts in place the institutional basis for a new regime of derisking as accumulation. The state comes under pressure to institutionally codify risk-proofing arrangements, guaranteeing private financial profits in the name of aligning sustainable projects with the preferred risk/return profile of institutional investors. This includes adopting the US model of private pensions and insurance to create local institutional investors. The tendency toward concentration in the asset management sector (to exploit economies of scale and scope) may result in Global North asset managers absorbing the funds of poor countries' institutional investors and making allocative decisions on a global level.

In pushing for financial system change, development as derisking threatens to render obsolete the old developmental banking model that put finance in the service of welldesigned industrial strategies. Development banks join the efforts of constructing and derisking development asset classes. This is a political choice. Developmental banking can arguably better serve a sustainability agenda because banks can easier include, monitor and enforce safeguard policies in long-term relationships with customers. Most countries with a successful experience of industrialisation relied on public development banking as a critical pillar of industrial policies (Naqvi et al, 2018). Public development banking allowed the developmental state to derisk via long-term loans to industrial sectors identified as strategic by an industrial policy aimed at promoting the international competitiveness of local firms.

The ambition to attract the portfolio glut structurally requires a financial system where credit creation occurs via securities (capital) markets, with longer intermediation 
chains, banks whose business model involves complex market-making activities in securities, derivative and repo markets, and complex requirements of tracing and regulating these markets. Historically, the only country that has successfully grown with a financial system organized around securities markets was the US in the $19^{\text {th }}$ century, in a unique set of circumstances that are unlikely to occur in developing/poor countries.

This re-engineering of financial systems in the Global South, threatens the space for alternative development strategies, and for a green developmental state. Government capacity to design autonomous policies, in many poor countries severely eroded by structural adjustment, will be further eroded by pressures to allocate scarce resources to creating the conditions for private development finance. Public resources have to be dedicated to de-risking "developmental" assets, to identifying "investable" developmental projects that can easily be transformed into tradable assets, to mopping up the costs of the financial crisis inevitable with this more fragile model, all the while dismantling the financial infrastructure that might support a green developmental state (including developmental banking by state-owned banks).

Approaching the financialisation of development as a paradigm shift under the banner of the Wall Street Consensus opens up a rich research agenda. How will the distributions of risks in PPP-led infrastructure projects be affected by the global pandemic and its impact on public finance in poor countries? What is the role of national development banks from the Global North and South in the process? What spaces of progressive resistance can be carved out in the evolving political economy of the Wall Street Consensus, and what politics of fiscal accountability is possible when derisking is codified in complex legal contracts? Given that the geographies of the Wall Street Consensus are uneven, how can we theorise the varieties of derisking states or capitalism, and how are these aligning with the growing political forces powering what Hendrikse (2020) terms neo-illiberalism, a symbiosis between neoliberal capitalism and variegated nationalisms? Under what conditions would it be possible to design developmental capital markets that work to finance a green developmental state, a state that carefully designs a just transition to a low carbon economy? How can we theorise the role of China as a global development actor in relationship to the Wall Street Consensus? 


\section{References}

Ajl, Max (2018) Beyond the Green New Deal. Available at https://brooklynrail.org/2018/11/field-notes/Beyond-the-Green-New-Deal

Akuno, K., and A. Nangwaya. 2017. Jackson Rising: The Struggle for Economic Democracy and Black Self-Determination in Jackson, Mississippi. Jackson, MS: Daraja Press.

Adrian, Tobias (2019) 'Assessing Global Financial Stability'. Cato Journal, 39, 339. Banse, Frauke (2019) 'Compact with Africa - der deutsche Beitrag zur Investitionsliberalisierung und Finanzialisierung in Afrika1'. Mimeo, University of Kassel.

Aoui, A., el Marani, M.A. and K. Rignall (2020) Global Aspirations and Local Realities of Solar Energy in Morocco. Available at https://merip.org/2020/10/global-aspirationsand-local-realities-of-solar-energy-in-morocco/

Asia Infrastructure Investment Bank (2019) Asian ESG Enhanced Credit Managed Portfolio ESG Framework. Available at https://www.aiib.org/en/projects/approved/2018/_download/regional/ESG-enhancedcredit-managed-portfolio.pdf

Baker, L. (2015) 'The Evolving Role of Finance in South Africa's Renewable Energy Sector.' Geoforum; Journal of Physical, Human, and Regional Geosciences 64: 146156. doi:10.1016/j.geoforum.2015.06.017.

Bayliss, Kate, and Van Waeyenberge, Elisa (2018) 'Unpacking the public private partnership revival', The Journal of Development Studies, 54(4), 577-593.

Bigger, P., \& Webber, S. (2020). Green Structural Adjustment in the World Bank's Resilient City. Annals of the American Association of Geographers, 1-16. 
Birdsall, N., \& Fukuyama, F. (2011) 'The Post-Washington Consensus', Foreign Affairs.

Bortz, Pablo and Kaltenbrunner, Anninna (2018) 'The international dimension of financialization in developing and emerging economies', Development and Change, 49(2), 375-393.

Bolton, P., Després, M., da Silva, L. A. P., Samama, F., \& Svartzman, R. (2020). The green swan. BIS Working Paper.

Braun, Benjamin (2020a) 'Central banking and the infrastructural power of finance: The case of ECB support for repo and securitization markets' Socio-Economic Review, 18 (2): $395-418$.

Braun, B. (2020b). American Asset Manager Capitalism. SocArXiv pre-print. https://doi.org/10.31235/osf.io/v6gue

Bruff, Ian (2014) 'The rise of authoritarian neoliberalism', Rethinking Marxism, 26(1), 113-129.

Bull, Benedicte and Miklian, Jason (2019) 'Towards global business engagement with development goals? Multilateral institutions and the SDGs in a changing global capitalism'. Business and Politics, 21(4), 445-463.

Carney, Mark (2020) 'Building a private financial system for net zero: priorities for private finance for COP26', https://ukcop26.org/wp-content/uploads/2020/11/COP26Private-Finance-Hub-Strategy_Nov-2020v4.1.pdf

Carroll, T., and D. S. L. Jarvis. (2014) Financialisation and Development in Asia. London: Routledge.

Christophers, Brett (2019) 'Environmental beta or how institutional investors think about climate change and fossil fuel risk' Annals of the American Association of Geographers, 109(3), 754-774. 
Converse, N., Levy-Yeyati, E., \& Williams, T. (2020). 'How ETFs amplify the global financial cycle in emerging markets', US Federal Reserve Discussion Paper 1268.

Dafermos, Y., Gabor, D. and Michell, J. (2020a) Institutional supercycles: an evolutionary macro-finance approach. Unpublished manuscript, UWE Bristol.

Dafermos, Y., Gabor, D. and Michell, J. (2020b) The Wall Street Consensus in pandemic times: what does it mean for climate-aligned development? Forthcoming in the Canadian Journal of Development Studies.

Dutt, D. (2020). Exorbitant Privilege or Ultimate Responsibility?: Access to the International Lender of Last Resort. Unpublished manuscript.

Deutsche Bank (2011) 'De-risking Clean Energy Business Models in a Developing Country Context', DB Climate Change Advisors https://www.db.com/cr/en/docs/GET_FiT_Plus.pdf

Dimakou, O., Romero, M. J., \& Van Waeyenberge, E. (2020). Never let a pandemic go to waste: turbocharging the private sector for development at the World Bank. Forthcoming, Canadian Journal of Development Studies.

Fichtner, Jan, Eelke M. Heemskerk, and Javier Garcia-Bernardo (2017) 'Hidden power of the Big Three? Passive index funds, re-concentration of corporate ownership, and new financial risk' Business and Politics 19, no. 2: 298-326

Fischer, Andrew (2019) 'Bringing Development Back into Development Studies'. Development and change, 50(2), 426-444.

Gabor, Daniela (2020) 'Critical macro-finance: a theoretical lens'. Finance and Society, forthcoming.

Gabor, Daniela (2019) 'Securitization for Sustainability: achieving the Sustainable Development Goals?' Report for the Heinrich Boll Foundation.

Gabor, Daniela (2018) 'Goodbye (Chinese) shadow banking, hello market-based finance'. Development and Change, 49(2), 394-419. 
Gabor, Daniela (2016). 'The (impossible) repo trinity: the political economy of repo markets'. Review of International Political Economy, 23(6), 967-1000.

Gabor, Daniela (2015) 'The IMF's rethink of global banks: critical in theory, orthodox in practice'. Governance, 28(2), 199-218.

Gabor, Daniela and Ndongo Samba Sylla (2020) Planting budgetary timebombs in Africa: the Macron Doctrine En Marche. Le Grand Continent.

Gevorkyan, Alexander and Kvangraven, Ingrid (2016) 'Assessing recent determinants of borrowing costs in sub-Saharan Africa'. Review of Development Economics, 20(4), 721-738.

Gelpern, Anna, \& Gerding, Eric (2016) 'Inside safe assets' Yale J. on Reg., 33, 363. Gonzalez, R., Khametshin, D., Peydró, J.-L. and Polo, A. (2019) 'Hedger of last resort: evidence from Brazilian FX interventions, local credit and global financial cycles'. Bank for International Settlements, BIS Working Paper No 832.

Gore, C. (2000) 'The rise and fall of the Washington Consensus as a paradigm for developing countries' World development, 28(5), 789-804.

Haggard, Stephen (2018). Developmental states. Cambridge University Press.

Haggard, Stephen (1990) Pathways from the periphery: The politics of growth in the newly industrializing countries. Cornell University Press.

Harvey, David (2003) The New Imperialism. Oxford, England/New York: Oxford University Press.

Hendrikse, R. (2020). The rise of neo-illiberalism. Mimeo.

Hördahl, Peter and Shim, Ilhyock (2020) 'EME bond portfolio flows and long-term interest rates during the Covid-19 pandemic'. BIS Bulletin no. 18. 
Hunter, B. M., \& Murray, S. F. (2019) 'Deconstructing the financialization of healthcare'. Development and Change, 50(5), 1263-1287.

Indigenous Environmental Network. 2018. "Indigenous Principles of Just Transitions." http://www.ienearth.org/justtransition/.

International Monetary Fund and World Bank (2020) 'Staff Note For The G20

International Financial Architecture Working Group: Recent Developments On Local Currency Bond Markets In Emerging Economies' available

at http://documents.worldbank.org/curated/en/129961580334830825/pdf/StaffNote-for-the-G20-International-Financial-Architecture-Working-Group-IFAWG-

Recent-Developments-On-Local-Currency-Bond-Markets-In-Emerging-

Economies.pdf

InterAmerican Development Bank (2017) Mobilising Private Capital for

Infrastructure: Lessons for Governments, Private Investors and Multilateral

Development Banks'

https://publications.iadb.org/publications/english/document/Mobilizing-Private-

Capital-for-Infrastructure-Lessons-for-Governments-Private-Investors-and-

Multilateral-Development-Banks.pdf

Institute of International Finance (2020) Letter to G20 Regarding the Debt Service Suspension Initiative, available at

https://www.iif.com/Portals/0/Files/content/Regulatory/IIF\%20Letter\%20to\%20G20 \%20on $\% 20$ DSSI $\% 20$ Sept $\% 202020 . p d f$

Jayadev, A., Mason, J. W., and Schröder, E. (2018) 'The Political Economy of Financialization in the United States, Europe and India' Development and Change, 49(2), 353-374.

Klagge, B., and Nweke-Eze, C. (2020) 'Financing large-scale renewable-energy projects in Kenya: investor types, international connections, and financialization'. Geografiska Annaler: Series B, Human Geography, 102(1), 61-83. 
Kentikelenis, A. E., \& Babb, S. (2019). 'The Making of Neoliberal Globalization: Norm Substitution and the Politics of Clandestine Institutional Change'. American Journal of Sociology, 124(6), 1720-1762.

Keucheyan, R. (2018). 'Insuring climate change: New risks and the financialization of nature'. Development and Change, 49(2), 484-501.

Lavinas, L. (2013) '21st Century Welfare’, New Left Review 84: 5-40.

Mawdsley, E. (2018). Development geography II: financialization. Progress in Human Geography, 42(2), 264-274.

Mazzucato, M. 2016. "From market fixing to market-creating: a new framework for innovation policy", Industry and Innovation, 23 (2): 140-156.

Mkandawire, Thandika. (2001) 'Thinking about developmental states in Africa.' Cambridge journal of economics 25.3 289-314.

Musthaq, F. (2020). Development Finance or Financial Accumulation for Asset Managers?: The Perils of the Global Shadow Banking System in Developing Countries. New Political Economy, 1-20.

Müller, Franziska (2020) 'Greening the anti-politics machine: De- and repoliticizing African renewable energy transitions', unpublished manuscript, University of Kassel. Nilsen, A. G. (2020). Give James Ferguson a Fish. Development and Change. 1-23. DOI: $10.1111 /$ dech.12618

Öniş, Z. (1991). The logic of the developmental state. Comparative Politics, Vol. 24, No. 1 (Oct., 1991), pp. 109-126.

Öniş, Z and Senses, F. (2005) 'Rethinking the emerging post-Washington consensus.', Development and Change, 36(2), 263-290. 
Perry, Keston (2021) Financing a Global Green New Deal: between techno-optimist renewable energy futures and taming financialization for a new "civilizing" multilateralism. Forthcoming, Development and Change.

Pozsar, Z. (2013). Institutional cash pools and the Triffin dilemma of the US banking system. Financial Markets, Institutions \& Instruments, 22(5), 283-318.

Pistor, Katarina. (2019). The Code of Capital: How the Law Creates Wealth and Inequality. Princeton University Press.

Rey, Helene. (2015). Dilemma not trilemma: the global financial cycle and monetary policy independence (No. w21162). National Bureau of Economic Research.

Rodrik, D. (2006). Goodbye Washington Consensus, Hello Washington Confusion?. Journal of Economic Literature, 44, 969-983.

Santoro, Paula Freire (2019). Inclusionary housing policies in Latin America: São Paulo, Brazil in dialogue with Bogotá, Colombia, International Journal of Housing Policy, DOI: 10.1080/19491247.2019.1613870

Storm, S. (2018). Financialization and economic development: a debate on the social efficiency of modern finance. Development and Change, 49(2), 302-329.

Sweerts, Bart, Francesco Dalla Longa, and Bob van der Zwaan. (2019) 'Financial DeRisking to Unlock Africa's Renewable Energy Potential'. Renewable and Sustainable Energy Reviews 102 (March): 75-82. https://doi.org/10.1016/j.rser.2018.11.039.

Wade, R. H. (2018). The developmental state: dead or alive?. Development and Change, 49(2), 518-546.

Williamson, J. (2000) 'What should the World Bank think about the Washington Consensus?'. The World Bank Research Observer, 15(2), 251-264. 
Williamson, J. (1993) 'Democracy and the "Washington consensus'. World development, 21(8), 1329-1336.

Yanagihara, T., \& Sambommatsu, S. (1996). 'Exchange rate fluctuations and Asian responses: growth strategy in the age of global money'. IDE Spot Survey. Tokyo: Institute for Developing Economies.

Volberding, P. (2018). Marketizing Development: KfW and the Rise of Financial Instruments for Development (Doctoral dissertation).

Wainwright, J., \& Mann, G. (2018). Climate Leviathan: A political theory of our planetary future. Verso Books.

World Bank (2017) 'Maximizing Finance for Development: Leveraging the private sector for growth and sustainable development'. Available at http://siteresources.worldbank.org/DEVCOMMINT/Documentation/23758671/DC20 17-0009_Maximizing 8-19.pdf

World Bank (2018a) 'Egypt: Enabling Private Investment and Commercial Financing in Infrastructure'. Egypt Multisector Infrastructure Assessment Program. https://www.worldbank.org/en/country/egypt/publication/egypt-enabling-privateinvestment-and-commercial-financing-in-infrastructure

World Bank (2018b) 'Vietnam: Maximizing finance for development in the energy sector'. InfraSAP Final Report.

http://documents.worldbank.org/curated/en/897271548259738578/Vietnam-

Maximizing-Finance-for-Development-in-the-Energy-Sector

World Bank (2019a) 'Sri Lanka: Energy InfraSAP'. Final Report. http://documents.worldbank.org/curated/en/843901561438840086/Sri-Lanka-EnergyInfrastructure-Sector-Assessment-Program-Executive-Summary 
World Bank (2019b) 'Nepal Infrastructure Sector Assessment', available at https://openknowledge.worldbank.org/bitstream/handle/10986/32355/134956.pdf?seq $\underline{\text { uence }}=1 \&$ is Allowed $=\mathrm{y}$

United National Development Program (2013) Derisking Renewable Energy Investment, available at https://www.undp.org/content/undp/en/home/librarypage/environmentenergy/low_emission_climateresilientdevelopment/derisking-renewable-energyinvestment/derisking-renewable-energy-investment.html United Nations Economic Commission for Africa (2020) Building forward together: financing a sustainable recovery for the future of all. Available at https://www.uneca.org/building-forward-together-financing-sustainable-recoveryfuture-all

United Nations Conference on Trade and Development (2019) Financing a Global Green New Deal. Trade and Development Report 2019. 